Journal of Money and Economy

Vol. 15, No. 4, Fall 2020

pp. 357-379

DOI: $10.29252 /$ jme.15.4.357

Original Research Article

\title{
The Impact of Macroprudential Policies on the Vulnerability of the Banking System: Dynamic Panel Model
}

\section{Nafiseh Keshtgar* \\ Seyed Hossein Mirjalili ${ }^{\text {t }}$}

Received: 2 Sep 2020
Mosayeb Pahlavani ${ }^{\dagger}$

Approved: 20 Feb 2021

In the aftermath of the global financial crisis (2007-2009), policymakers in the developing countries and emerging economies have generally relied on macroprudential policies to achieve financial stability. Since the banking system's vulnerability plays an essential role in financial instability, and the banking system's stability is exposed to vulnerability, we examine macroprudential policies' effectiveness in reducing banking vulnerability and economic instability through containing credit growth. We estimated a dynamic panel for 14 Iranian banks using GMM and ArellanoBovar / Blundell-bond two-stage estimators during 2009-2018. The results indicate that the increase in lending rates in the interbank market leads to the banking system's contraction of lending capacity. The positive and significant effect of the economic growth index indicates the banks' procyclical behavior. That financial institutions in the business cycles behave procyclical in lending. The diminishing effect of the macroprudential policy index on the bank credit expansion indicates that macroprudential authority and policy tools' application reduces the banking system's instability and vulnerability. Therefore, to reduce financial intermediation instability, the financial sector regulator can institutionalize macroprudential policies.

Keywords: Bank Credit, Macroprudential Policy, GMM Dynamic Panel, Iranian Banking.

JEL Classification: C22, C82, E32, E44, G01.

\footnotetext{
* Faculty of Economics and Management, University of Sistan and Baluchestan, Zahedan, Iran.; n.keshtgar@gmail.com (Corresponding Author)

$\dagger$ Faculty of Economics and Management, University of Sistan and Baluchestan, Zahedan, Iran; pahlavani@eco.usb.ac.ir

$\$$ Faculty of Economics, Institute for Humanities and Cultural Studies, Tehran, Iran; h.jalili@ihcs.ac.ir
} 


\section{Introduction}

Banks provide loans, but overdue accumulation takes part of the banks' assets out of credit management. It reduces the quality of assets, which exposes the banks to financial instability.

A reason for banks' fragility in the face of financial crises stems from their intermediary nature. Banks' balance sheets usually have maturity mismatches. On the other hand, banks cannot quickly call for loans, and there is a kind of inflexibility in the banks' assets in this regard. Therefore, due to the vulnerabilities that financial institutions, especially banks, are exposed to and the inherent fragility of these institutions, they require constant vigilance. (Zalbegi Darestani, 2014)

Bank performance plays a major role in the country's economic growth and makes growth happen by providing investors' funds and realizing financial deepening. (Keshtgar et al., 2020a)

Countries' economic stability is indebted to their financial stability, and financial stability as the core of monetary and financial activities is critical. Goodhart (2008) shows that financial crises mostly stem from bank instability. Therefore, identifying and monitoring the soundness and stability of banks is of great importance.

Credit expansion can pave the way for further economic growth, but financial crises often occur after the sudden growth in bank credit. During the boom period, lending to the private sector expands rapidly and may lead to low-productivity projects and increasing household consumption. (Keshtgar et al., 2019b)

Due to the high share of the banking system in the financing, any instability affects Iran's economy. Evidence from the Iranian economy suggests that the banking system has faced challenges in granting loans, which have led to the instability of the financial sector. In this paper, due to the importance of banking stability and its components, we seek to understand how prudential measures affect banking stability. 


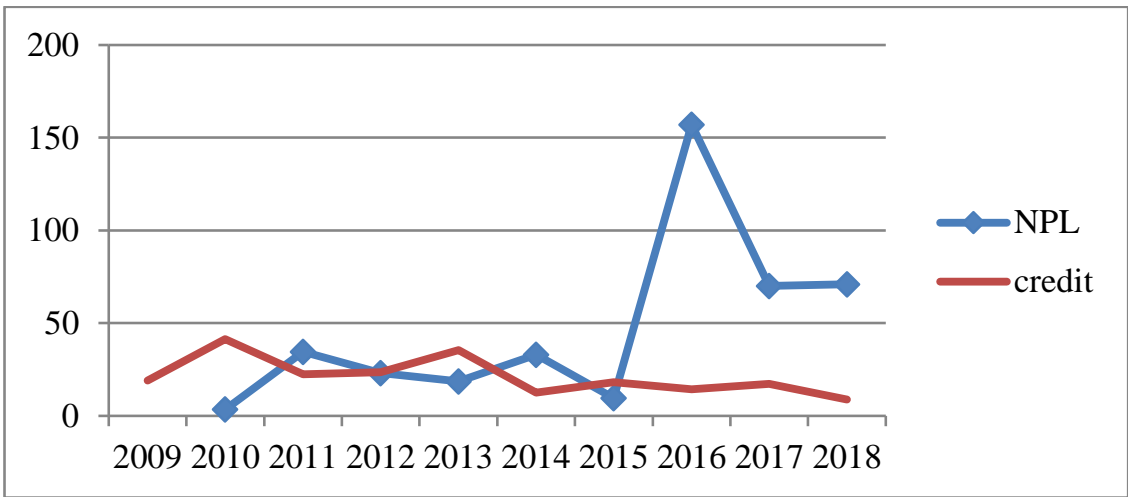

Figure 1. Granted loans and NPL.

Source: report of banking system performance in Iran

Figure (1) shows that during 2009-2015, the trend of granted loans and non-performing loans was volatile, during which non-performing loans are low. Lower levels of non-performing loans were due to the Central Bank's control over banks' overdrafts. Also, the increase in the bank's profit rates gives rise to a downward trend. But from 2015 to 2018, despite the slow increase in lending, the increase of non-performing loans increased sharply. In recent years, non-performing loans have increased, which may enhance credit risk and bank instability. It will adversely affect the balance sheet of banks.

In addition to the increase of non-performing loans, given that a proportion of banks' assets are spent accumulating fixed and non-cash assets, part of banks' lending capacity depends on the turnover of these assets and their liquidity. In a recession, with declining asset prices and liquidity of fixed assets such as real estate in the banks' balance sheet, lending capacity decreases, leading to credit restrictions and financial frictions (Dargahi \& Hadian, 2018).

Since the 1980s, in which financial liberalization and deregulation of financial markets were implemented, the frequency and severity of financial crises have increased. The most recent example of which was the global financial crisis (2007-2009). Financial crises' recurrence revealed the inadequacy of macroeconomic policies, micro-prudential regulations, and other policies to ensure financial stability. The emergence of financial crises strengthened the view that systemic risks are possible even in a seemingly calm economic environment. These crises have shown that specific financial policies must control systemic risks; in other words, financial stability does 
not necessarily arise as an effect of macroeconomic policies, and achieving this goal requires macroprudential policies.

The term macroprudential was first used in the late 1970s in a study on banks' international lending by the Monetary-Exchange Committee of the Bank for International settlement (Clement, 2010). Crockett (2000) was also one of the first to raise the need for macroprudential policies.

As defined by the International Monetary Fund as well as the Bank for International Settlement, macroeconomic policies have been defined as essential tools for systemic risk reduction (BIS, 2011; IMF, 2011a)

Stabilization policies, in addition to improving the macroeconomic environment, reduce financial instability. Although these policies are essential for financial stability, they are not sufficient, as achieving financial stability, in addition to macroeconomic policies, requires specific policies. The policies are known in the recent economic literature as macro-prudential.

Many countries have benefited from macroprudential policies as a front line of defense against the risk of financial instability. Curbing banking credit growth has often been followed by macroprudential policies. These policies have also been used cumulatively, and their restrictive measures appear in the months to come.

Applying macroprudential tools in the aftermath of the global financial crisis has increased the resilience of financial institutions and borrowers against adverse economic shocks and curbing excessive credit growth (IMF, 2013).

Macroprudential policies are the reason for externalities and market failure in financial intermediaries and markets that can lead to a procyclical and systemic risk and financial crisis. Simultaneously, pro-cyclicality and systemic risk can be attributable to many factors, including macroeconomic shocks to market foundations (such as commodity price shocks) and monetary policy deficiencies. Macroprudential policies can mitigate financial cycles or discipline large financial institutions. Externalities and other market failures also justify macroprudential policies as well.

Macroprudential policy tools can be classified in many ways. One classification is that it could be classified into five categories. First, tools that impose quantitative restrictions on borrowers, financial instruments, or activities. Second, tools for capital requirement or provisioning. Third, tools that impose other quantitative restrictions on the balance sheet of financial institutions. Fourth, tools that levy tax on activities or composition of the balance sheet. Fifth, tools that impose other accounting measures, such as changes in the compensation and so on. The first four categories control 
changes over time, financial institutions, or situations, while the fifth are structural measures. The first set of policies aim to control the financing demand, while the rest will affect the financing supply. The purpose of macroprudential policy is to strengthen the financial system's defense in the face of financial or economic shocks and, thus, the supply of credit and other financial services in adverse economic conditions. By creating and releasing buffers as needed, macro-prudent policies can help reduce the recurrence of financial crises or moderate or severe contractions.

The increase of non-performing loans is a problem of the banking system in Iran. This increase reflected in the banks' credit risk and resulted in a decline in bank assets' value and profitability and, consequently, financial instability. Therefore, the study's main question is if the implementation of the macroprudential policies reduces the vulnerability of the banking system. The purpose of the study is to identify the effects of the macroprudential policies on the vulnerability of the banking system in Iran".The study's novelty is that it is pioneering academic research on the effects of the macroprudential regulations on Iran's banking stability using the regression analysis. The distinction of this study with others is in the purpose, method, and instruments.

This paper is organized as follows. The second section is devoted to the literature review .In the third section, we discuss some introduces theoretical issues. The fourth section describes the methodology. The fifth and sixth sections describe data and empirical models. The sixth section is devoted to model data. Finally, section seven presents our conclusions.

\section{Literature Review}

In their study, Lim et al. (2011) found that applying macroprudential tools reduces the cyclicality of credit and GDP growth. It happens by reducing the correlation between credit and GDP growth. Using data from 49 countries, they assessed macroprudential tools' effectiveness in reducing systemic risk over time and across institutions and markets. The result suggests that macroprudential policy tools effectively reduce cyclicality, but the effectiveness is sensitive to the kind of shock that the financial sector is facing. Based on these findings, they identified the conditions under which macroprudential policies are more likely to succeed, as well as the conditions under which macroprudential policies may have little effect.

Acharya (2013) explored the impact of macroprudential policies on financial risk and suggested that the risk weights set for achieving macro prudential objectives lead to financial risk. As placing higher weights on some assets encourages that assets that are not subject to special regulations are not 
deemed risky. It has a role to play in banking vulnerability against systemic risk.

Kuttner and Shim (2013) examined whether monetary policy instruments, other than the interest rate and macroprudential instruments, help stabilize the housing prices and the housing credit, using data from 57 countries covering three decades. Their panel regression found that macroprudential tools have a significant effect on housing credit growth. The housing sector's risk is constrained by controlling housing credit growth by limiting the loan-to-value ratio and the loan interest-to-income repayment ratio. Among the policies implemented, a change in property tax is a policy tool with a sensible impact on house price appreciation.

Claessens et al. (2014) examined how changes in the bank's balance sheet respond to the macroprudential policies. They explored how these policies affect systemic financial risk in a panel of 48 countries over the period 2000 to 2010. They found that measures such as targeting borrowers (i.e., the cap for debt-to-income ratio and the loan-to-value ratio), curbing credit growth, and restricting foreign exchange lending are effective measures to reduce financial asset growth. In other words, such measures are effective in reducing bank leverage and non-performing loan. Counter-cyclical reserve also reduces bank leverage.

Zhang and Zoli (2014) examined the effect of macroprudential tools in 13 Asian and 33 other economies since 2000. They explored the issue through event study, macro-level national panel regression, and bank-level micropanel regression. The analysis suggests that these measures curbed housing price growth, stock flows, credit growth, and banking leverage. The cap on the loan-to-value ratio has been the most effective. The study suggests that macroprudential policy limited housing price growth, credit growth, and bank leverage. The effective tools are the loan-to-value ratio caps, housing tax, and foreign currency measures.

Aiyar et al. (2014) examined the effect of macroprudential regulation in the United Kingdom, using banks' data. They indicated that banks' requirement to raise capital is somewhat ineffective because they increase lending by foreign bank branches. But smoothing the credit cycle is a central element in the macroprudential regime. For these regulations to effectively control credit supply, it is needed first to increase capital requirement. Regulating a bank's capital is a central element of macro-prudential policy in smoothing the credit cycle. Second, banks that are not under the regulation will be able to counteract the lending of affected banks. They discussed the UK's evidence in which bank regulators imposed a minimum requirement of 
Basel regulations for banks. They indicated that the banks' regulations had reduced British banks lending in response to stringent requirements. Banks that are not subject to these regulations (branches of foreign banks) have not reduced their lending. Regulating a bank's capital is a central element of macro-prudential policy in smoothing the credit cycle.

Bruno et al. (2015) examined how macroprudential policies related to financial outcomes in 12 Asia-Pacific countries. They found evidence that macroprudential policies are more successful when coupled with a tightening monetary policy.

Akinci and Rumsey (2018) analyzed macroprudential policies in 57 countries from 2000 to 2013 with the tightening and easing of seven macroprudential tools. The findings are; first, macroprudential policies have become more widely used in advanced and emerging economies in the aftermath of the global financial crisis. Second, macroprudential policies targeted, primarily, the housing sector, especially in developed countries. Third, such policies have usually been implemented through banks' reserve requirements, capital flow restrictions, and monetary policy. Fourth, tightening due to macroprudential policies is associated with lower credit growth and housing price control. Fifth, targeted policies seeking to limit housing price growth, particularly in countries where banks have a large role in housing finance, have appeared highly effective.

Fendoglu (2017) examined the effectiveness of macroprudential policy instruments on the credit cycle in the emerging market economies. The model estimation results indicated that borrower-based instruments and reserve requirements are the most effective tools. Weaker results appeared for foreign currency-related macroprudential instruments.

Dargahi and Hadian (2018) examined the role of macroeconomic policies in the financial stability of Iran's economy during 1369-1394 using the DSGE model. The results indicate that the existence of macroprudential authority and the implementation of policy tools such as loan-to-value ratio and countercyclical capital buffer by reducing the procyclical movement of financial variables leads to reducing instability and vulnerability of the financial sector.

Altunbas et al. (2017) examined the effect of macroprudential policy on banking risk through a panel of 61 advanced and emerging economies. They find that there is evidence that macroprudential instruments have a significant effect on banking risk. Moreover, the response to macroprudential instruments varies between banks, depending on their balance sheet. Small banks with lower capital and a large share of wholesale financing respond more robust to macroprudential instruments. They also find that, by controlling each bank's 
specific characteristics, macroprudential policies are more effective in the tightening phase than in the easing one.

Davis et al. (2019) examined the macroeconomic impact of macroprudential policies by evaluating the costs and benefits of two policy instruments: The loan-to-value ratio in mortgages and the bank's variable objectives. They focused on Germany, Italy, and the United Kingdom. They found that the loan-to-value ratio has a lower effect on the likelihood of crisis than capital adequacy. A systemic risk index reveals the likelihood of a banking crisis and the need for a macroprudential mechanism. However, there are significant variations between countries. Also, the introduction of macroprudential policy in the pre-crisis has led to an improved macroeconomic environment, and hence, the probability of a crisis has decreased.

\section{Theoretical Issues}

Bank stability can reflect the capital structure of the bank and its financing. Bank's capital can help banks compensate for financial losses and reduce shock transmission and the risk of banks' lending process. (Van den Heuvel, 2012)

A loan is a component of a bank's assets and constitutes a major part of banks' interest income (or profit), and is an essential element in a bank's financial performance and stability. Also, a non-performing loan is a criterion for measuring a bank's performance (Vatansever and Hepsen, 2013).

The globalization of banking activity transfers shocks affecting a particular country or a bank to the real sector of the local economy and the financial system and the real economy of other countries. The banking system is more vulnerable to shocks and contagion. This contagious effect was further felt at the onset of the 2007-2009 financial crisis, which began with the US housing bubble bursting and rising mortgage default. The turning point came when the US government refused to save Lehman Brothers Financial Services from bankruptcy on September 15, 2008. The bankruptcy shocked market confidence and caused turmoil, and the global financial system spread the crisis. Financial institutions' financial stress spread to other institutions and led to a shock that threatened the financial system and created systemic risk. It also exacerbated the need to measure financial stability. The impact of a shock on each financial institution indicates its vulnerability. (Claessens et al., 2014)

As the sole supplier of bank reserves, the central bank responds to banks' demand for reserves. Therefore, the banking crisis happens by a sharp increase 
in the volume of lending to banks by the central bank, which indicates a banking incident and is in line with the intensification of credit supply and a deepening of the financial cycle. (Keshtgar et al., 2020b)

When banks rely on short-term funding and borrowing from interbank market increases, they expose to funding and liquidity shocks. As in the recent financial crisis, these vulnerabilities reduce the bank's ability to acquire resources and refinance under stress and can cause sudden deleveraging and short sales effects throughout the system (Covitz et al., 2009).

Banking crises, which are reflected in the financial markets, are due to the banking system's rapid credit growth. The acceleration of credit precedes banking crises (Keshtgar et al., 2019a).

There are two approaches to macroprudential policies; One approach highlights that for is about those who tend to "borrow more" without internalizing the impact of their decisions. Macroprudential policies can make them internalize such externalities (Korinek, 2009; Bianchi and Mendoza, 2010; Jeanne \& Korinek, 2010; and Bianchi, 2011).

The second approach focuses on the role of macroprudential policies in adjusting the procyclical movement, which originates from financial friction. It, therefore, reduces the cyclical effect of macroeconomic shocks. This research line provides an analytical framework in which the optimal combination of monetary and macroprudential policies can be studied. Of course, macroprudential policies' effectiveness depends on the ongoing assessment of financial conditions, especially systemic risks.

The reasons for implementing macroprudential policies are: First, the high correlation in financial institutions' performance results in contagion effects. It can cause financial distress and give rise to systemic risk. Second, the potential that strong credit cycles may not only aggravate the business cycle but also lead to systemic banking distress. In a broader sense, we can distinguish between the cross-section dimension of macroprudential instruments (i.e., higher capital requirements or regulatory constraints on institutions whose failure will have a stronger negative impact on the entire financial system) and the time-series dimension, which aims at smoothing credit cycles and reducing the impact of credit cycle on the bank solvency.

In the literature on the transmission mechanism of monetary policy, there are several issues on the impact of macroprudential policies. First, these policies are endogenous, towards able to smooth out the credit cycle. In particular, macroprudential policy responses should be considered more effective during the boom phase in tempering the credit cycle. The resulting reserves can mitigate the credit cycle. Put differently, there may be a timing 
issue that obscures the relationship between macroprudential policies and credit flows and makes it difficult to make a causal statement. Second, we need to separate the demand for and supply of credit, as changes in macroprudential policies can affect both demand and supply. Third, changes in macroprudential policies may lead to a change in other policies, most notably monetary policy.

The literature on the relationship between macroprudential policies and financial stability could be divided into two categories: The first category includes country studies examining the relationship between macroprudential policies and credit growth or the growth of other financial indicators.

The IMF (2013b) also examined how changing policies affect the financial vulnerability (credit growth, portfolio investment flows, and housing prices) and real sector of the economy (product growth and credit allocation among economic activities).

Lim et al. (2011) analyzed the relationship between macroprudential policies and credit and leverage developments. They found evidence that policies such as a cap on loan-to-value (LTV) and debt-to-income (DTI), credit growth ceiling, statutory reserve (RR), and dynamic reserve rules give rise to the reduction in the cyclicality mitigation of the Credit cycle and leverage.

They concluded that both the capital requirements and the statutory reserve have a significant and negative relationship with credit growth. Also, LTV restriction and the capital requirement are strongly correlated with the low rates of home value increase. Moreover, the statutory reserve is associated with a decrease in the portfolio investment inflows for the emerging markets where the exchange rate is floating.

The second category focuses on the relationship between macroprudential policies and the financial crisis and banks' risk and international financing developments. In this vein, Dell'Ariccia et. al. (2012) find that macroprudential policy mitigates the likelihood of the credit boom and banking crisis. Moreover, the policy reduces the risk of stagnation while simultaneously decreases the risk of adversely affecting the rest of the economy from financial sector problems. Credit rationing is the one that the banks do if high-risk customers are seeking credit. In other words, they reduce the amount of lending.

Banks' lending is based on the market conditions, and therefore the banks' lending behavior is affected by current and future macroeconomic conditions. According to Baum et al. (2004), with the increase of if uncertainty prevails in the economy, it is difficult to predict the rate of return on banks' lending. A 
stable macroeconomic environment makes it easier to predict project returns, and therefore credits are allocated to the projects with the higher expected returns. By decreasing uncertainty, banks thereby increase the ratio of lending to assets. But if the uncertainty prevails in the economy, banks will reduce lending to assets ratio (Tari et al., 2012).

In the recession and the sharp decline in the sales and volume of the economic activities, the banking crisis began and expanded. A prominent feature of the crisis was the loss of confidence and bankruptcy of the creditors in financial institutions. Hence, the debtors' inability to repay due to their unemployment or low income during the recession led to increased nonperforming loans. And as a result, their reserves are reduced. Then, meeting their obligations to depositors became harder, and the credit and liquidity risks increased. Consequently, liquidity risk rises. The increase of non-performing loans also reduced banks' ability to lend. Therefore, the financial crisis prompted depositors to withdraw and due to the systemic risk, the bankruptcy of small banks happened which was contagious to the banking system. A lesson learned from the crisis was that a bank's sufficient capital is very important and indicating the health soundness of a financial institution (Noori et al., 2009).

Banks can rely on their capital to cope with non-performing loans, unfavorable market conditions, and some operating bottlenecks. This paper has measured the ratio of capital adequacy ratio as a macroprudential policy index measured by dividing equity by total assets and has been used as an explanatory variable. We also used credit risk as a variable in the model to indicate the banking system's vulnerability. Credit risk is important and sensitive in monetary and credit institutions because the resources used for allocation are the monetary institution's debt to shareholders, people, and banks. In particular, in the balance sheet of a monetary institution, credits are considered outstanding, and individuals' deposits are considered future debts. It means that collecting installments is not for sure, but the payment of debts (deposits) is required. Otherwise, the monetary institution will face bankruptcy (Bozorg Asl et al., 2017).

There are instruments to improve bank soundness and resilience to shock. These instruments can be divided into two groups: quantitative restrictions on balance sheet ratios (such as loan-to-deposit ratio (LTD)) or price-based criteria (such as commissions, expenses, taxes, etc.) (Perotti and Suarez, 2011)

The Capital Adequacy Ratio (CAR), by increasing the banks' resilience during the boom period, provides a stable supply of credit in times of 
recession. Also, releasing it useful in financial bottleneck will help absorb losses, reduce vulnerabilities, and prevent credit crunch (Aiyar et al., 2014).

In this study, we used the leverage ratio as a ratio of debt to equity. leverage ratio also affects the bank's ability to increase the overall size of its risk-taking. (assets) relative to its ability to absorb losses (capital) (Haldane, 2013). In the absence of these tools or inefficiency of tools in decreasing credit growth, some countries used credit growth ceiling (CC).

\section{Methodology}

The statistical population of this study includes 14 Iranian banks from 2010 to 2019. The banks include Eqtesad Novin, Pasargad, Tejarat, Tose Saderat, Refah, Saman, Sepah, Sarmayeh, Saderat, Industry and Mine, Karafarin, Keshavarzi, Maskan, and Mellat. The data were collected based on the data available from the banks' financial reports and the Central Bank data. We examined the issue using GMM and Stata software.

The first-order difference of the generalized method of moments (GMM) was first suggested by Arellano and Bond (1991). In the first-order differential method of Arellano and Bond, the lag of the dependent variable is added to the right side of the equation. The first-order differential variables are derived, and then the model is estimated. Arellano \& Bover (1995) and Blundell \& Bond (1998) proposed an orthogonal Generalized Method of Moments (GMM) by modifications in the first-order differential method of GMM. The difference between Arellano-Bond and Arellano-Bover / Blundell-Bond is based on how individual effects are included in the model.

An advantage of the second method over the first one is the increase in accuracy. It also reduces the sample size limitation bias, making the estimates more efficient (Baltagi, 2008).

To estimate the panel, we applied a two-stage Arellano -Bover / BlundellBond by dynamic panel estimator (DPD) (Arellano and Bond, 1991):

$y_{i t}=\sum_{j=1}^{p} \alpha_{j} y_{i, t-j}+x_{i t} \beta_{1}+w_{i t} \beta_{2}+v_{i}+\varepsilon_{i t}$

$\alpha_{j}: p$ number of parameters to be estimated.

$x_{i t}$ : A vector of $1 \times k_{1}$ which is a strictly exogenous covariate.

$\beta_{1}$ : A vector $k_{1} \times 1$ of the parameters that will be estimated.

$w_{i t}$ : A vector of $1 \times k_{2}$ which is predetermined or exogenous variables.

$\beta_{2}$ : A vector $k_{2} \times 1$ of the parameters that will be estimated.

$v_{i}$ : Panel level effect (which may be correlated with explanatory variables). 
$\varepsilon_{i t}$ : has an independent and identical distribution (i.i.d) in the whole sample with variance $\sigma_{\varepsilon}^{2}$.

It is also assumed that $\varepsilon_{i t}$ and $v_{i}$ for each cross-section $i$ are independent of $t$ over the whole period. $x_{i j}$ and $w_{i t}$ may include the lags of exogenous and dummy variables. The lag dependent variable results in the correlation of the explanatory variables and the unobserved panel level effects $v_{i}^{2}$ and the inconsistency of the standard estimators.

Arellano and Bond estimator is based on the first-order differential to remove panel level effects and utilize instrumental variables to form the moment conditions.

Arellano and Bover (1995), Blundell and Bond (1998) proposed a system of estimators used for a level of moment conditions by entering the differential gap as a tool and then on moment condition by entering the level gap as tools for differential equations.

The second stage moment condition is valid if the initial condition $E\left[v_{i} \Delta y_{i 2}\right]=0$ is valid for all $\mathrm{i}$ (Blundell \& Bond, 1998; Blundell Bond \& Windmeijer, 2000).

The GMM estimator consistency depends on the validity of the assumption of non-serial correlation of error terms and tools that can be tested by two tests specified by Arellano and Bond (1991), Arellano and Bover (1995), and Blundell and Bond (1998). The first is the Sargan test of predetermined constraints that test the validity of the tools. The J-statistic (Sargan) test has a $\chi^{2}$ distribution with degrees of freedom equal to the number of excessive constraints.

The second is a serial correlation test, which tests second-order serial correlations in the first-order differential error terms by $M_{2}$ statistic. In this test, the GMM estimation is consistent if there is no second-order serial correlation in the error terms from the first-order differential equation.

Non-rejection of the null hypothesis of both tests provides evidence for the assumption of non-serial correlation and the validity of the tools. We applied the Sargan test to evaluate the consistency of GMM estimation. For statistic and econometric analysis, Stata software was used.

\section{Empirical Model}

The dynamic panel data regression model provided by Arellano and Bond (1991) was a basis for other empirical works such as Kuttnner and Shim (2013). We benefited from both in this study. Arellano and Bond estimation 
is known to correct the estimation bias and is thus the most widely used technique for estimating dynamic panel data models.

We studied 14 Iranian banks over the period 2010-2019 using STATA 14 and Eviews 9. The econometric model is as follows:

$C_{i, t}=\eta_{i}+\sum_{k=1}^{p_{1}} \rho_{k} C_{i, t-k}+\beta V I X_{t}+\sum_{k=1}^{p_{2}} \theta_{k} X_{i, t-k}+\delta M A P P_{i, t-1}+\varepsilon_{i, t}$

i: denotes countries, t: denotes time and $\eta_{i}$ : denotes constant.

The independent variable $\mathrm{C}(\mathrm{i}, \mathrm{t})$ denotes the annual growth rate of domestic bank credit.

MAPP is an indicator of macroprudential policy. We have benefited from the cumulative method for panel data analysis because macroprudential tools (capital adequacy ratio, financial leverage, and loan-to-deposit ratio) may affect bank credit growth not only in the season of implementation of macroprudential policy but also in the subsequent seasons.

The vector $X_{i, t}$ denotes annual real GDP growth with two lags and a change in the interbank market lending rate. VIX: a proxy for credit risk-averse, credit risk representing the ratio of non-performing loan to total assets. The conditions of the real and financial sectors in an open and small economy are highly correlated with credit risk conditions. The lag in the dependent variable as an explanatory variable appeared in the regression to correct the sequential correlation in the error terms.

The model is estimated using the GMM method for the dynamic panel. It reduces concerns about being endogenous.

We estimated the correlation between macroprudential policy instruments for each country and the correlation between macroprudential and monetary policy instruments.

\section{Data}

Table (1) provides the mean, standard deviation, and max-min of Iranian banks' data (2010 to 2019).

Table 1

Statistical Properties of the Data

\begin{tabular}{lllllll}
\hline Descriptive Statistic & Credit & Credit(-1) & MAPP & GDP(-2) & PR & CR \\
\hline Mean & 19.05 & 23.12 & 7.02 & -0.51 & 21.79 & 10.89 \\
Standard deviation & 16.97 & 19.65 & 4.56 & 6.90 & 2.79 & 7.72 \\
Max & 77.99 & 126.92 & 21.15 & 5.90 & 27 & 52.32 \\
Min & -35.25 & -8.68 & 1.41 & -18.11 & 18.68 & 1.18 \\
\hline
\end{tabular}

Source: Research Findings 
Table (2) describes the variables of the model.

Table 2

Model Variables

\begin{tabular}{|c|c|c|c|}
\hline Variable & Abbreviation & Description & source \\
\hline $\begin{array}{l}\text { Credit growth } \\
\text { (billion Rials) }\end{array}$ & Credit & $\begin{array}{l}\text { Growth of lending by } \\
\text { banks and credit } \\
\text { institutions }\end{array}$ & $\begin{array}{l}\text { Central Bank } \\
\text { Monetary Indicators }\end{array}$ \\
\hline $\begin{array}{l}\text { Macroprudentialpolicy } \\
\text { index (Percent) }\end{array}$ & MAPP & $\begin{array}{l}\text { Standardized and } \\
\text { weighted index of } \\
\text { LEV, LTD, and CAR }\end{array}$ & Iran Banking Institute \\
\hline $\begin{array}{l}\text { Non-oil GDP Growth } \\
\text { (billion Rials) }\end{array}$ & GDP & $\begin{array}{l}\text { Gross Domestic } \\
\text { Product Annual } \\
\text { Growth }\end{array}$ & $\begin{array}{l}\text { Central Bank } \\
\text { Database }\end{array}$ \\
\hline $\begin{array}{l}\text { Interbank market } \\
\text { lending rates } \\
\text { (percent) }\end{array}$ & PR & $\begin{array}{l}\text { Interbank market } \\
\text { lending rates }\end{array}$ & $\begin{array}{l}\text { Central Bank } \\
\text { Indicators }\end{array}$ \\
\hline $\begin{array}{l}\text { Credit Risk Index } \\
\text { (percent) }\end{array}$ & CR & $\begin{array}{l}\text { Ratio of non- } \\
\text { performing loan to } \\
\text { Total Assets }\end{array}$ & Iran Banking Institute \\
\hline
\end{tabular}

Note: LEV: Financial Leverage is a ratio of debt (borrowed funds) to equity.

LTD: Loan-To-Deposit ratio.

CAR: Capital Adequacy Ratio is the ratio of a bank's capital to its risk.

The ratio of non-performing loans to assets shows the risky behavior and caution of the bank in lending. Credit risk is the probability of a change in the value of a bank's assets due to unforeseen changes in customers or debtors' credit quality. It emanates from the default risk and the risk of changed customer's credit conditions and occurs when the contracting party cannot pay its debts or at least does not pay them on time (Mujtahid and Hassanzadeh, 2005: 385).

Macroprudential policy index calculated cumulatively. It includes capital adequacy ratio, loan-to-deposit ratio, and financial leverage.

\section{Estimation and Results}

To estimate the model by the GMM method, it is necessary to use instrumental variables. Two important issues in selecting instrument variables are: first, more instrumental variables do not mean better estimation. Second, instrumental variables should be selected based on their ability to estimate and specification of circumstances.

If adding a new instrumental variable positively affects the quality of the estimation, it will be used as the instrumental variable. Still, if adding an 
instrumental variable makes collinearity between the instrumental variables, error in the model, deterioration of model estimation conditions, or corner results for the parameters, the instrumental variable will not be used.

Although the GMM method does not require many assumptions about the data, it is important to check the variables' stationarity before model estimation. The results of the unit root test for the variables are depicted in Table (3). Based on the Levin-Lin-Chu test, the null hypothesis that is the existence of the unit root is rejected. It means that all variables are stationary.

Table 3

Model Variables; stationary Test

\begin{tabular}{lllll}
\hline Variable & $\begin{array}{l}\text { Levin-Lin-Chu } \\
\text { test statistic }\end{array}$ & Probability & $\begin{array}{l}\text { Degree of } \\
\text { stationary }\end{array}$ & Difference or level \\
\hline Credit & -6.88 & 0.000 & $\mathrm{I}(0)$ & stationary at the level \\
MAPP & -5.32 & 0.000 & $\mathrm{I}(0)$ & stationary at the level \\
GDP & -8.63 & 0.000 & $\mathrm{I}(0)$ & stationary at the level \\
$\mathrm{Pr}$ & -7.05 & 0.000 & $\mathrm{I}(0)$ & stationary at the level \\
$\mathrm{Cr}$ & -4.45 & 0.000 & $\mathrm{I}(0)$ & stationary at the level \\
\hline
\end{tabular}

Source: Research Findings

The mentioned moment conditions are valid when there is no serial correlation in the error terms. Arellano and Bond have developed a method for testing the first and second-order autocorrelation. For the first-order difference of errors, the removal of panel-level effects is required. It is needed that the first-order Autoregressive AR(1) coefficient is significant, and the second-order Autoregressive $\mathrm{AR}(2)$ coefficient is insignificant (Greene, 2003). In the dynamic panel model (DPD), when the error term has an identical and independent distribution (iid), the first-order difference of errors $V_{i t}$ has a first-order correlation.

Therefore, in Table (3), the coefficient of first-order Autoregressive AR(1) is significant at the $1 \%$ level, which means the null hypothesis that the nonautocorrelation of the first-order difference of error term is rejected. As stated above, this is a specification of a dynamic panel model (DPD).

However, the existence of serial correlations in the higher than the firstorder difference of error terms like AR(2) implies that the moment conditions for conducting the Arellano-Bond autocorrelation test are not valid (Arellano \& Bond, 1991).

Thus, the second-order autoregressive AR(2) coefficients in Table(4) model are not significant. The null hypothesis that the quadratic non-serial 
correlation of first-order difference cannot be rejected. As such, there is no explicit bias in the estimated model.

Table 4

Model estimation results; GMM method

\begin{tabular}{lllll}
\hline Variable & Coefficient & standard deviation & z statistic & $\begin{array}{c}\text { probability } \\
\text { level }\end{array}$ \\
\hline Credit(-1) & -0.21 & 0.10 & -2.00 & 0.04 \\
MAPP & -4.68 & 1.57 & -2.97 & 0.00 \\
GDP(-2) & 0.34 & 0.17 & 1.91 & 0.05 \\
Pr & -0.88 & 0.38 & -2.29 & 0.02 \\
Cr & -1.99 & 1.69 & -1.18 & 0.23 \\
Constant & 78.82 & 16.74 & 4.71 & 0.00 \\
\hline \multicolumn{5}{c}{ model specification tests } \\
\hline Sargan test \& Bond & AR(1) & 9.84 & 1.00 \\
Arellano \& & -2.11 & 0.03 & \\
serial autocorrelation & AR(2) & -0.37 & 0.70 & \\
test & & 35.51 & & \\
Wald test & & & 0.00 & \\
\hline
\end{tabular}

Source: Research findings

Thus, in the GMM method, to remove the autocorrelation between the lagged dependent variable and error terms, the variable lag is used as an instrumental variable (IV) in the two-stage Arellano-Bover / Blondell-Bond estimator.

Given that the consistency of the two-stage Arellano-Bover / BlondellBond estimator depends on the validity of the tools used in the estimation, the Sargan test is conducted to verify the instruments' validity and to prove the validity for over-identifying restrictions. Only when the error terms variance is not heteroscedastic, Sargan test has asymptotically chi-square distribution.

Arellano and Bond (1991) indicated that the one-step Sargan test is rejected for variance heteroscedasticity (Baltaji, 2008). (That is, the test's power is in favor of the opposite assumption, and the distribution is not asymptotically standardized).

The results of the estimation using data from 2010 to 2019 are shown in Table (4). The GMM estimator's consistency depends on the validity of the assumption of non-serial correlation of error terms and tools. It is noteworthy that the $\mathbf{J}$ (Sargan) test is provided for over-identifying restrictions to measure how the sample moment condition is close to zero.

The test statistic has an asymptotic $\chi^{2}$ distribution with $\mathrm{R}$ degrees of freedom. $\mathrm{R}$ is the number of instrumental variables with a fixed value 
(orthogonal constraints or moment conditions). The estimation result in Table (4) shows that the identification conditions are met in the GMM method. Therefore, the results can be trusted.

Based on the model estimation results in Table (4), it can be seen that all the variables except the credit risk are significant at a 95\% confidence level. In other words, the model's explanatory variables have a significant effect on the growth of bank credit.

In this estimation, the Sargan test was used to check the validity of the tool matrix. As noted above, in this test, the null hypothesis indicates that tools are not correlated with the error terms. As can be seen, the null hypothesis, that tools are not correlated with error terms, cannot be rejected. Therefore, it can be concluded that the tools used for the estimation are valid.

The Lending lag coefficient is significant, which implies that banks' lending behavior follows a dynamic model. In other words, the coefficient of -0.21 indicates that the amount of loan granted in the current period is negatively correlated with the loan in the previous period. The increase in lending in each period is a reason for its decline in the following period. There are several reasons for this, given the specific circumstances of the Iranian economy. It appears to be due to the increased non-performing loans.

The economic growth index with a coefficient of 0.34 indicates that increased economic growth leads to increased bank lending. Real GDP growth reflects a bust and boom of business cycles. In times of recession, the problem of loan repayment increases. Therefore, the impact of this variable on the financial instability of commercial banks is of great importance. The results indicate that increasing economic growth leads to a decrease in financial instability and, in other words, to financial stability in commercial banks.

The Credit risk index has a coefficient of -1.99. It indicates that the increase in credit risk leads to a lower lending level. But it is insignificance, which means the increase in the non-performing loans provides a basis for a lending decrease. The process of this effect is that. The credit risk increases as the banks' outstanding claims increase. As the share of the non-performing loans increases, the bank's financial health soundness is affected, and banks' willingness to lend decreases. The recent banking crises and the nature of the banks' activities have further highlighted the importance of risk management. The Central Bank also required the establishment of a risk committee at the bank. Part of the banks' lending is obligatory and is paid based on the budget law. Therefore, Iranian public banks cannot resist such regulations despite the credit risk. 
As an instrumental variable with a coefficient of -0.88 , the interbank market lending rate has a significant effect on the bank's credit behavior. The process of this effect is that with increasing the interbank market lending rate, banks face a high-interest rate for granting loans in the interbank market, and thus reduces bank lending.

Undermining the credit cycle is an objective for the macroprudential policy, which is a conservative strategy. There is a need for additional financial "regulation" to join macroeconomic models. Therefore, to examine the vulnerabilities associated with credit over-expansion and its consequences, macroprudential policies are needed to address such vulnerabilities and reduce systemic financial risks. (Pahlavani et al., 2018)

\section{Concluding Remarks}

The macroprudential policy is critical in the credit market and affects the credit behavior of the banks. We examined the role of the macroprudential policies in reducing the instability and vulnerability of the banks. Given the effective role of the macroprudential policies in reducing the banks' instability and vulnerability, it is recommended that the regulator of the financial system implement macroprudential policies to improve financial stability and reduce bank vulnerability.

We examined the determinant of bank lending behavior through the macroprudential measures and the macroeconomic indicators. The data were extracted from the financial reports of 14 Iranian banks over the period 20102019. The panel data model was estimated using the panel data and based on the Generalized Method of Moment (GMM).

The findings of the study are as follows:

- Bank lending follows a dynamic process. The lending amount in the previous period affects the lending in the next one.

- The macroprudential policy index has a negative and significant effect on the expansion of credit in the Iranian banks. The application of macroprudential policies in the money and credit market serves as a buffer against the excessive expansion of lending and avoids credit instability in the banking system. As can be seen from the results, the effects of macroprudential measures are significant. If the prudential policies in the banking system are not utilized, the average credit growth will increase significantly over time.

The economic growth index indicates a positive and significant effect on the lending growth of Iran's banking industry. Increased economic growth 
results in increased bank lending. The results suggest that increasing economic growth leads to a decrease in financial instability.

- The credit risk index, derived from the ratio of non-performing loans to total assets, indicates a negative effect on lending expansion but is not statistically significant. As part of public banks' lending are obligatory and is paid based on the government budget notes. Therefore, banks do not resist such instruction despite their credit risk.

- Interbank market lending rates indicate a negative and significant relationship between the bank's lending and the interbank market, meaning that increasing lending rates in the interbank market leads to a shrinking of bank lending.

According to the results of this study, given the effective role of the macroprudential policies in reducing instability and vulnerability of the banking system, it is recommended that the financial supervisor be institutionalized the macroprudential policy to improve financial stability, as the Basel III Regulatory Framework proposes to build counter-cyclical capital reserves for the stability of the banking system over the periods of rapid credit growth in the money and credit markets.

\section{References}

Acharya, V. V. (2013). Adapting Micro Prudential Regulation for Emerging Markets.

In Dealing with the Challenges of Macro Financial Linkages in Emerging Markets (pp. 57-89). The World Bank.

Akinci, O., \& Olmstead-Rumsey, J. (2018). How effective are macroprudential policies? An empirical investigation. Journal of Financial Intermediation, 33, 33-57. https://doi.org/10.1016/j.jfi.2017.04.001

Altunbas, Y., Binici, M., \& Gambacorta, L. (2017). Macroprudential Policy and Bank Risk. BIS Working Paper. No. 646

Arellano, M., \& Bond, S. (1991). Some Tests of Specification for Panel Data: Monte Carlo Evidence and an Application to Employment Equations. The Review of Economic Studies, 58, 277-297.

Arellano, M., \& Bover, O. (1995). Another Look at the Instrumental Variable Estimation of Error-Components Models. Journal of Econometrics. 68: 29-51.

Aiyar, S., Calomiris, C. W., \& Wieladek, T. (2014). Does macroprudential regulation leak? Evidence from a UK policy experiment. Journal of Money, Credit, and Banking. 46 (s1), 181:214.

Baltagi, B. (2008). Econometric Analysis of Panel Data (4th ed.). John Wiley \& Sons, Ltd. 
Baum, C. F., Çağlayan, M., \& Özkan, N. (2004). The Second Moment's Matter: The Response of Bank Lending Behavior to Macroeconomics Uncertainty. University of Leicester Working Paper, 4 (13), 1-36.

Bianchi, J. \& Mendoza, E. (2011). Overborrowing, Financial Crises, and MacroprudentialPolicy. IMF Working Paper. 11(24).

BIS (2011). Macroprudential policy tools and frameworks. Progress report to the G20 (Basel: October), Financial Stability Board, Bank for International Settlement.

Bozorg Asl, M., Bbarzideh, F., \& Samadi, M. T. (2017). The Impact of Combined Liquidity Risk and Credit Risk on Financial Stability of Iranian Banking Industry. Monetary \& Banking Research, 10(33), 509-532.

Blundell, R., \& Bond, S. (1998). Initial Conditions and Moment Restrictions in Dynamic Panel Data Models. Journal of Econometrics. 87: 115-143.

Blundell, R., Bond, S. \& Windmeijer, F. (2000). Estimation in Dynamic Panel Data Models: Improving the Performance of the Standard GMM Estimator. The Institute for Fiscal Studies. WP 00/12.

Bruno, V., Shim, I., \& Shin, H. S. (2015). Comparative Assessment of Macroprudential Policies. Monetary and Economic Department. Bank for International Settlements (BIS) Working Papers. No 502.

Claessens, S., Ghosh, S. R., \& Mihet, R. (2014). Macroprudential Policies to Mitigate Financial System Vulnerabilities. International Monetary Fund (IMF) Working Papers. No. 14/155.

Clement, P. (2010). The Term Macroprudential: Origins and Evolution. BIS Quarterly Review, March, 59-67.

Covitz, D., Liang, N., \& Suarez, G. (2009). The Evolution of a Financial Crisis: Runs in the Asset-Backed Commercial Paper Market. Board of Governors of the Federal Reserve System, Working Paper, (2009-36).

Crockett, A. (2000). Marrying the Micro- and Macroprudential Dimensions of Financial Stability, BIS Speeches, 21 September (Bank of International Settlements).

Dargahi, H., \& Hadian, M. (2018). The Effect of Macroprudential Policies on Financial Stability of Iran Economy: DSGE Approach. Journal of Monetary and Banking Research, 10 (34), 559-590.

Davis, E. P., Liadze, I., \& Piggott, R. (2019) Assessing the Macroeconomic Impact of Alternative Macroprudential Policies. Economic Modelling, 80. 407-428.

Dell'Ariccia, G., Igan, D., Laeven, L., \& Tong, H. (2012). Policies for Macrofinancial Stability: How to Deal with Credit Booms. International Monetary Fund (IMF) Staff Discussion Note. No. 12/06.

Fendoglu, S. (2017). Credit Cycles and Capital Flows: Effectiveness of the Macroprudential Policy Framework in Emerging Market Economies. Journal of Banking \& Finance. Vol.79, 110-128.

Goodhart, C. A. (2008). The Regulatory Response to the Financial Crisis. Journal of Financial Stability, 4(4), 351-358. 
Greene, W. H. (2003). Econometric Analysis. New York University. 7th ed. New Jersey, Upper Saddle River: Pearson Education, Inc. 07458.

Haldane, A. G. (2013). Constraining Discretion in Bank Regulation. Bank of England Speech, Speech given at the Federal Reserve Bank of Atlanta Conference on Maintaining Financial Stability: Holding a Tiger by the Tail(s). Federal Reserve Bank of Atlanta.

International Monetary Fund. (2011). Macroprudential policy: an organizing framework. https://www.imf.org/external/np/pp/eng/2011/031411.pdf.

International Monetary Fund. (2013b). Key aspects of macroprudential policy. Background paper. IMF Policy Paper.

IMF (2011a). Macroprudential Policy: An Organizing Framework, (Washington: International Monetary Fund).

IMF, Dec. (2012). The Interaction of Monetary and Macroprudential Policies. Background Paper. Tech. rep., International Monetary Fund.

IMF (2013). Key Aspects of Macroprudential Policy_Background Paper, IMF Policy Paper. Washington: International Monetary Fund.

Jeanne, O., \& Korinek, A. (2010). Managing Credit Booms and Busts: A Pigouvian Taxation Approach, NBER Working Paper 16377.

Keshtgar, N., Pahlavani, M., \& Mirjalili, S. H. (2019a). Features of the Financial Cycle in Iran's Economy. Journal of Applied Economics Theories. 6(2), 135-160.

Keshtgar, N., Pahlavani, M. \& Mirjalili, S. H. (2019b). Identification of Financial Markets' Cycle and Its Relationship to Exchange Rate Fluctuations in Iran. Iranian Economic Journal: Macroeconomics (IEJM). 14(28).

Keshtgar, N., Pahlavani, M. \& Mirjalili, S. H. (2020a). The Impact of Exchange Rate Volatility on Banking Performance (case of Iran). International Journal of Business and Development Studies. 12(1). PP. 41-58.

Keshtgar, N., Pahlavani, M. \& Mirjalili, S. H. (2020b). Macroprudential Policies and Financial Cycle in Iran. Manuscript, Faculty of Economics and Management, University of Sistan and Baluchestan.

Korinek, A. (2009). Systemic Risk-Taking: Accelerator Effects, Externalities, and Regulatory. Mimeo, University of Maryland.

Kuttner, K. N., \& Shim, I. (2013). Can Non-Interest Rate Policies Stabilize Housing Markets? Evidence from a Panel of 57 Economies. National Bureau of Economic Research (NBER) Working Papers, No. 19723.

Levin, A., Lin, C. F., \& Chu, C. (2002). Unit Root Tests in Panel Data: Asymptotic and Finite-Sample Properties. Journal of Econometrics, 108, 1-24.

Lim, C. H., Costa, A., Columba, F., Kongsamut, P., Otani, A., Saiyid, M., Wezel, T., \& Wu, X., (2011). Macroprudential Policy: What Instruments and How to Use Them? Lessons from Country Experiences. International Monetary Fund (IMF) Working Papers. No. 11/238

Noori, P., Ghaderi, O., \& Madani Esfahani, M. (2009). The Role of Financial Crises in Key Indicators of Banks. Proceedings of the 20th Islamic Banking Conference, Tehran, Iran Institute for Banking Education. 
Mujtahid, A., \& Hassanzadeh, A. (2005). Money, Banking, and Financial Institutions. Tehran, Monetary and Banking Research Institute. Central Bank of the Islamic Republic of Iran.

Pahlavani, M., Keshtgar, N. \& Mirjalili, S. H. (2018). Interaction of Financial and Business Cycles (Case of Iran). Journal of Financial Economics. 12(43), 1-19.

Perotti, E. C., \& Suarez, J. (2011). A Pigovian Approach to Liquidity Regulation. International Journal of Central Banking, 7(4), 3-41.

Tari, R., Yiğitbaş, B. Ş., \& Kurt, S. (2012). Asimetrik Bilgi, Banka Kredileri Ve Reel Sector Arasındaki Ilişkilerin Ampirik Analizi. Gaziantep University Journal of Social Sciences, 11(4), 1248-1274.

Van den Heuvel, S. (2012). Interest Rate Risk and Bank Equity Valuations. Finance and Economics Discussion Series from the Board of Governors of the Federal Reserve System (U.S.). NO.26.

Vatansever, M. \& Hepsen, A. (2013). Determining Impacts on Non-Performing Loan Ratio in Turkey. Journal of Finance and Investment Analysis. 2(4), 119-129.

ZalbgiDarestani, H. (2014). Main Determinants of Stability in Iran's Banking System. Journal of Monetary \& Banking Research, 7(20), 307-327.

Zhang, L., \& Zoli, E. (2014). Leaning Against the Wind: MacroprudentialPolicy in Asia. International Monetary Fund (IMF) Working Papers. No. 14/22. 